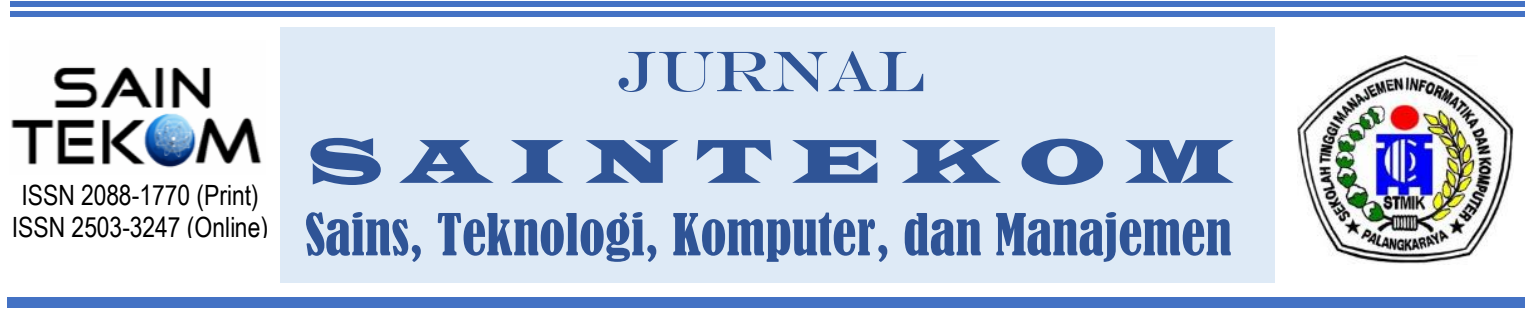

\title{
PENERAPAN METODE APRIORI SEBAGAI SISTEM PENDUKUNG KEPUTUSAN PEMBENTUKAN PAKET PENJUALAN BIBIT BUAH
}

\author{
*Rifqi Hammad ${ }^{1}$, Veny Cahya Hardita ${ }^{2}$, Muhammad Zulfikri ${ }^{3}$, Eka Wahyu \\ Sholeha ${ }^{4}$ \\ ${ }^{1)}$ Rekayasa Perangkat Lunak, Universitas Bumigora \\ Jl. Ismail Marzuki No. 22 Mataram \\ ${ }^{2)}$ Teknik Informatika, STMIK Palangkaraya \\ Jl. G. Obos No.114, Menteng, Kec. Jekan Raya, Kota Palangka Raya, Kalimantan \\ Tengah \\ ${ }^{3)}$ Ilmu Komputer, Universitas Bumigora \\ Jl. Ismail Marzuki No. 22 Mataram \\ 4)Teknologi Informasi, Politeknik Negeri Tanah Laut \\ Jl.Ahmad Yani Km. 6, Desa Panggung, Kec. Pelaihari, Kab. Tanah Laut, Prov. \\ Kalimantan Selatan \\ Email: rifqi.hammad@universitasbumigora.ac.id, vencahya@stmikplk.ac.id, \\ mzulfikri@universitasbumigora.ac.id,ekawahyus@politala.ac.id
}

\begin{abstract}
Taletan Ijo is an online shop that sells fruit seeds. In carrying out its business processes, he utilizes a sales information system. The system is used to manage sales data. If the data is not used, it will lead to accumulation of data but lack of information. Taletan ijo uses the manual method in its product marketing strategy so that the strategy used is not quite right. Stored sales transaction data can be used as a reference in making marketing strategies such as making product sales packages. This study uses data mining methods, namely associations with a priori algorithms to process transaction data into information that can help support decisions in determining marketing strategies. The results of the study show that the lift ratio test results obtained are 3.2 which indicates that the value is valid with a minimum number of transactions of 10 and a confidence value of 80 .
\end{abstract}

Keywords: Apriori, Data Mining, Association, Taletan Ijo.

\section{ABSTRAK}

Taletan Ijo adalah toko online yang memiliki usaha dalam penjualan bibit buah. Dalam menjalakan proses bisnisnya, ia memanfaatkan system informasi penjualan. Sistem tersebut digunakan untuk mengelola data penjualan. Data tersebut apabila tidak dimanfaatkan, akan menimbulkan penumpukan data namun minim informasi. Taletan ijo menggunakan metode 
manual dalam strategi pemasaran produknya sehingga strategi yang digunakan kurang tepat. Data transaksi penjualan yang tersimpan dapat digunakan sebagai acuan dalam membuat startegi pemasaran seperti pembuatan paket penjualan produk. Penelitian ini menggunakan metode data mining yaitu asosiasi dengan algoritma apriori untuk mengolah data transaksi menjadi informasi yang dapat membantu mendukung keputusan penentuan strategi pemasaran. Hasil dari penelitian menunjukkan bahwa hasil uji lift ratio yang didapatkan adalah 3,2 yang menunjukkan bahwa nilai tersebut valid dengan jumlah transaksi minimal 10 dan nilai confidence 80 .

Kata kunci : Apriori, Data Mining, Asosiasi, Taletan Ijo.

\section{PENDAHULUAN}

Saat ini banyak pengusaha dalam menjalankan usahanya sudah menerapkan teknologi informasi. Namun dalam penerapannya sering kali teknologi informasi yang dimiliki tidak dimanfaatkan secara maksimal (Riszky \& Sadikin, 2019). Taletan Ijo adalah salah satu toko online yang memiliki usaha dalam penjualan bibit buah seperti bibit buah berbagai jenis kelengkeng, manga, jambu, durian dan lain-lain. dalam menjalakan proses bisnisnya, Taletan Ijo telah memanfaatkan sistem informasi untuk membantunya. Salah satunya adalah sistem informasi penjualan. Sistem informasi ini digunakan untuk menyimpan data penjualan yang mana nantinya menghasilkan informasi terkait penjualan berupa laporan penjualan. Data penjualan tersebut apabila dibiarkan begitu saja akan menimbulkan penumpukan data namun minim informasi sehingga menjadi kurang bermanfaat (Fitriyani, 2015).

Dalam dunia bisnis saat ini, persaingan antar pengusaha semakin ketat sehingga membutuhkan suatu strategi yang dapat meningkatkan penjualan produknya (Aziz, 2017). Taletan Ijo saat ini masih menggunakan metode manual dalam strategi pemasaran produknya sehingga tidak memiliki acuan yang dapat menyebabkan strategi yang digunakan tidak tepat guna. Data transaksi penjualan yang disimpan pada sistem informasi penjualan didapat digunakan sebagai acuan dalam membuat strategi pemasaran (Firmansyah \& Merlina, 2020) seperti pembuatan paket penjualan produk (Widjaya, 2017). Data-data tersebut dianalisis kemudian diekstraksi untuk menghasilkan informasi yang terkandung di dalamnya sehingga dapat membantu dalam pengambilan keputusan (Oktaviani et al., 2019). 
Salah satu teknik yang dapat digunakan untuk mengekstraksi data tersebut adalah data mining yang mana data mining merupakan proses yang menggunakan beberapa rumpun ilmu seperti statistik, matematis, kecerdasan buatan, dan teknik machine learning untuk mengekstrak dan menganalisa informasi dan pengetahuan yang berguna berasal dari basis data (Phindika et al., 2021). Data mining memiliki beberapa teknik antara lain seperti eksplorasi data, segmentasi, pelanggan, aturan asosiasi, time series, dan lain sebagainya (Packianather et al., 2017). Dari beberapa metode data mining yang disebutkan, metode asosiasi merupakan metode yang paling banyak digunakan untuk mengetahui pola hubungan antar produk sehingga dapat membantu dalam strategi pemasaran pembuatan paket produk (Sudrajat \& Ermatita, 2021). Tujuan dari asosiasi adalah untuk menemukan hubungan antar produk yang telah dibeli atau yang ada pada data transaksi penjualan untuk mendapatkan pola dari data tersebut (Sudrajat \& Ermatita, 2021). Apriori merupakan salah satu metode yang ada pada aturan asosiasi data mining. Penggunaan metode apriori dapat menghasilkan informasi berupa pola penjualan produk dan dapat digunakan untuk mengembangkan strategi pemasaran (Hermaliani et al., 2020).

Berdasarkan latar belakang diatas, penelitian ini membahas tentang penerapan metode apriori sebagai sistem pendukung keputusan dalam pembentukan paket produk yang mana dapat dijadikan sebagai rekomendasi dalam strategi pemasaran. Terdapat beberapa penelitian terdahulu yang berkaitan dengan penelitian yang dibahas pada artikel ini. Artikel yang ditulis oleh Abdul Harist, Ibnu Rasyi dan Angga Putra Juledi yang berjudul "Implementasi Data Mining Algoritma Apriori untuk meningkatkan penjualan". Pada penelitian ini, peneliti menerapkan metode apriori untuk mengetahui pola pembelian produk dari jumlah transaksi sebanyak 209 dengan variasi produk berjumlah 45 produk. Penelitian ini menghasilkan bahwa produk yang paling sering dibeli adalah puding stroberi dan vanila. Dengan mengetahui produk yang paling banyak terjual dan pola pembelian barang yang dilakukan konsumen, Lakoe Dessert Pondok Kacang dapat mengembangkan strategi pemasaran untuk memasarkan produk lain dengan menganalisis keuntungan 
dari penjualan terbanyak (Nst et al., 2021). Letak perbedaan penelitian yang ditulis oleh Abdul Hasrist dan kawankawan adalah pada penelitian tersebut menghasilkan informasi produk yang paling sering dibeli, sedangkan pada penelitian ini hasil yang diharapkan adalah berupa pembentukan produk yang dapat digunakan sebagai strategi pemasaran untuk meningkatkan penjualan produk.

\section{METODE}

Pada penelitian ini terdapat beberapa tahapan yang dilakukan. Tahapan-tahapan tersebut dapat dilihat pada Gambar 1.

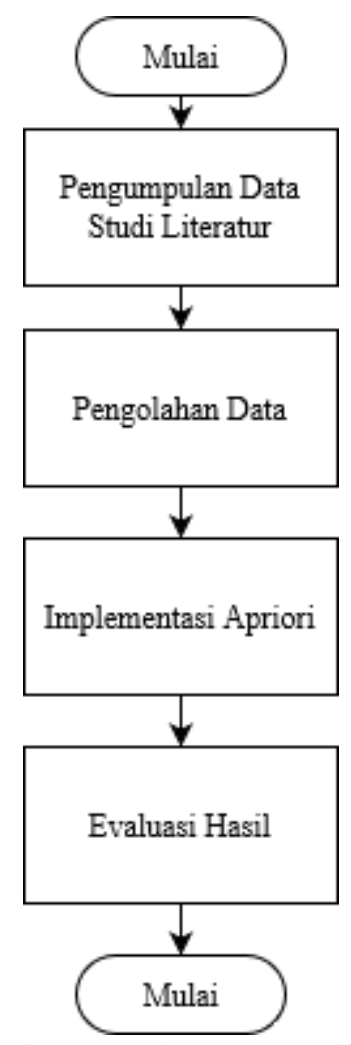

Gambar 1. Tahapan Penelitian
Gambar 1. Menunjukkan tahapantahapan yang dilakukan pada penelitian ini. Tahapan pada penelitian ini dimulai dari pengumpulan data dan studi literatur. Setelah dilakukannya pengumpulan data dan studi literatur tahapan berikutnya adalah pengolahan data. Pengelolaan data ini dilakukan sebelum masuk kedalam tahapan implementasi apriori yang mana digunakan untuk mempermudah tahapan implementasi apriori. Tahapan selanjutnya adalah implementasi apriori dan evaluasi hasil.

\subsection{Pengumpulan Data}

Data yang digunakan pada penelitian adalah data transaksi penjualan pada Taletan Ijo yang dimulai dari tanggal 1 Maret 2021- 1 April 2021 dengan jumlah jenis bibit adalah 24 Jenis Bibit. Data transaksi yang digunakan pada penelitian ini dapat dilihat pada Tabel 1.

Tabel 1. Data Transaksi Penjualan

\begin{tabular}{|c|l|}
\hline Tanggal & \multicolumn{1}{|c|}{ Produk Terjual } \\
\hline 2021-03-01 & $\begin{array}{l}\text { Kelengkeng Aroma Durian, } \\
\text { Jeruk Sunkist, Durian } \\
\text { Musangking, Kelapa Hibrida, } \\
\text { Jambu Deli }\end{array}$ \\
\hline 2021-03-01 & $\begin{array}{l}\text { Alpukat Markus, Cempedak, } \\
\text { Jambu Deli, Jeruk Nagami, } \\
\text { Anggur Brazil }\end{array}$ \\
\hline 2021-03-02 & $\begin{array}{l}\text { Jambu Merah, Jeruk Nipis, } \\
\text { Durian Oci, Alpukat } \\
\text { Alligator, Alpukat Mentega }\end{array}$ \\
\hline 2021-03-02 & $\begin{array}{l}\text { Jambu Merah, Jeruk Nagami, } \\
\text { Kelengkeng merah }\end{array}$ \\
\hline
\end{tabular}




\begin{tabular}{|c|l|}
\hline Tanggal & \multicolumn{1}{|c|}{ Produk Terjual } \\
\hline$\ldots \ldots \ldots \ldots \ldots$ & $\ldots \ldots \ldots \ldots \ldots \ldots \ldots \ldots \ldots$ \\
\hline 2021-04-01 & $\begin{array}{l}\text { Alpukat Markus, Nangka } \\
\text { Genjah, Jambu Merah }\end{array}$ \\
\hline
\end{tabular}

Tabel 1 menunjukkan sebagian data penjualan produk yang dimiliki oleh Taletan Ijo periode 1 Maret 2021 - 1 April 2021.

\subsection{Studi Literatur}

\section{a. Data Mining}

Data Mining merupakan teknik yang digunakan untuk menemukan pengetahuan yang berasal dari tumpukan data (Rusdiansyah et al., 2020). Data mining dimanfaatkan untuk menggali dan menganalisis data dalam jumlah yang banyak dan menemukan pola yang ada pada data tersebut (Rodiyansyah, 2015). Pada data mining terdapat beberapa tahapan yaitu data cleaning, data integration, data selection, data transformation, data mining, data evaluation, dan presentation (Romadhon \& Kodar, 2020).

\section{b. Association Rule Mining}

Analisis asosiasi merupakan teknik data mining yang digunakan untuk menemukan kombinasi item yang muncul dalam waktu yang bersamaan (Rasyidah \& Dwiasnati, 2021). Terdapat dua ukuran yang digunakan dalam asosiasi yaitu support dan confidence. Support merupakan ukuran yang digunakan untuk menunjukkan seberapa besar tingkat kombinasi dari suatu itemset dari semua transaksi. Sedangkan confidence merupakan ukuran yang digunakan untuk menunjukkan hubungan antara dua item atau lebih berdasarkan kondisi tertentu.

\section{c. Apriori}

Algoritma apriori merupakan salah satu Algoritma asosiasi yang dapat digunakan untuk menentukan hubungan aturan kombinasi dari suatu item (Syahrir \& Fatimatuzzahra, 2020). Untuk menemukan kombinasi item atau produk yang memenuhi syarat minimum dari nilai support yang mana untuk mencari nilai support dari sebuah item dapat dilihat pada persamaan 1, untuk mencari nilai support dari dua item dapat dilihat dari persamaan 2 dan untuk mencari nilai support dari kombinasi tiga item dapat dilihat pada persamaan 3 (Wahyuningtias \& Rusdiansyah, 2019).

Support $(A)=$ $\frac{\text { ETransaksi Mengandung A }}{\text { Total Transaksi }} \times 100 \%$

Support $\left(A_{1} B\right)=$ ETransaksi

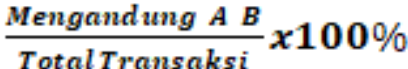

Support $(A, B, C)=$ ¿Transaksi Mengandung $A, B C$ Total Transaksi $\boldsymbol{x} 100 \%$ 
Setelah mendapatkan pola dan aturan pembentukan aturan asosiasi, langkah berikutnya adalah mencari nilai confidence dengan menghitung aturan dari asosiatif $\mathrm{A} \cup \mathrm{B}$ yang mana untuk menghitung nilai confidence tersebut dapat dilihat pada persamaan 4 (Phindika et al., 2021). Aturan asositif tersebut digunakan untuk mencari aturan asosiasi yang akan dipilih berdasarkan urutan support $\mathrm{X}$ confidence.

\section{Confidence $P(B \mid A)=$ ¿Transaksi$$
\frac{\text { Mengandung A B }}{\text { Total Transaksi }} x \mathbf{1 0 0} \%
$$$$
\text { Mengandung } A
$$

\subsection{Implementasi Apriori}

Implementasi apriori pada penelitian ini dimulai dari pemilihan range data yang akan digunakan kemudian menentukan nilai support dan confidence-nya. Setelah itu dilakukan proses pencarian dan pembentukan kandidat yang memenuhi nilai support. Pembentukan aturan confidence untuk membentuk aturan dari asosiasi sehingga menghasilkan hasil akhir.

\subsection{Evaluasi Hasil}

Evaluasi hasil dilakukan dengan menggunakan uji lift rasio. Uji lift ratio digunakan untuk menguji hasil data mining yang mana hasil tersebut seharusnya dapat memberikan pengetahuan kepada pengguna dengan ketepatan lift ratio. Mengukur ketepatan dari hasil asosiasi yang telah terbentuk dapat menggunakan persamaan 5 (Fauzy et al., 2016) (Riszky \& Sadikin, 2019).

$$
\text { Lift Ratio }=\frac{\text { Confidence }(A, B)}{\text { Bencmark Confidence }}
$$

Untuk mencari nilai benchmark confidence dapat menggunakan persamaan 6.

\section{Benchmark Confidence $=$ Jumlah Transaksi Item Consquent Jumlah Transaksi Keseluruhan}

Setelah mendapatkan nilai uji lift ratio, nilai tersebut diukur, apakah nilainya lebih dari 1 atau kurang dari 1. Jika nilai uji lift ratio lebih dari 1 maka dapat dinyatakan valid dan sebaliknya (Fauzy et al., 2016).

\section{HASIL DAN PEMBAHASAN}

\subsection{Pengolahan Data}

Data transaksi yang ditunjukkan pada Tabel 1 diolah untuk mendapatkan jumlah transaksi dari masing-masing item produk pada Taletan Ijo. Adapun hasilnya dapat dilihat pada Tabel 2 .

Tabel 2. Jumlah Transaksi Produk

\begin{tabular}{|l|l|c|}
\hline No & \multicolumn{1}{|c|}{ Nama } & Jumlah \\
\hline 1 & Kelengkeng merah & 7 \\
\hline 2 & Kelengkeng Aroma durian & 19 \\
\hline 3 & Kelengkeng Matalada & 4 \\
\hline 4 & Jambu Merah & 12 \\
\hline
\end{tabular}




\begin{tabular}{|l|l|c|}
\hline No & \multicolumn{1}{|c|}{ Nama } & Jumlah \\
\hline 5 & Jambu Kristal & 5 \\
\hline 6 & Anggur Brazil & 5 \\
\hline 7 & Mangga Golek India & 7 \\
\hline 8 & Alpukat Markus & 8 \\
\hline 9 & Alpukat Mentega & 8 \\
\hline 10 & Cempedak & 9 \\
\hline 11 & Nangka Genjah & 7 \\
\hline 12 & Alpukat Aligator & 10 \\
\hline 13 & Jambu Kristal Varigata & 9 \\
\hline 14 & Kelapa Hibrida & 9 \\
\hline 15 & Jeruk Sunkist & 22 \\
\hline 16 & Jeruk Purut & 10 \\
\hline 17 & Jeruk Santang Madu & 6 \\
\hline 18 & Jeruk Nipis & 13 \\
\hline 19 & Jeruk Nagami & 11 \\
\hline 20 & Jambu Deli & 10 \\
\hline 21 & Durian Oci & 8 \\
\hline 22 & Durian Musangking & 20 \\
\hline 23 & Durian Mentega & 13 \\
\hline 24 & Durian Si Gundul & \\
\hline
\end{tabular}

\subsection{Pembentukan Itemset}

Tabel 2. Menunjukkan jumlah transaksi dari masing-masing produk. Setelah mendapat data transaksi dari masingmasing produk kemudian dilakukan analisis untuk mencari data yang sesuai dengan parameter yang digunakan. Parameter yang digunakan adalah nilai minimal jumlah transaksi produk adalah 10 dengan nilai minimal support 15,625 dan minimal confidence 80. Dengan ketentuan tersebut maka didapatkan pembentukan itemset 1 yang memenuhi parameter. Adapun hasil pembentukan itemset 1 dapat dilihat pada Tabel 3 .
Tabel 3. Itemset 1 yang Memenuhi Parameter

\begin{tabular}{|l|l|c|c|}
\hline No & \multicolumn{1}{|c|}{ Nama } & Jumlah & Support \\
\hline 1 & $\begin{array}{l}\text { Kelengkeng } \\
\text { Aroma durian }\end{array}$ & 19 & 29,69 \\
\hline 2 & Jambu Merah & 12 & 18,75 \\
\hline 3 & $\begin{array}{l}\text { Alpukat } \\
\text { Aligator }\end{array}$ & 10 & 15,63 \\
\hline 4 & Jeruk Sunkist & 22 & 34,38 \\
\hline 5 & Jeruk Purut & 10 & 15,63 \\
\hline 6 & Jeruk Nipis & 13 & 20,31 \\
\hline 7 & Jeruk Nagami & 11 & 17,19 \\
\hline 8 & Jambu Deli & 10 & 15,63 \\
\hline 9 & $\begin{array}{l}\text { Durian } \\
\text { Musangking }\end{array}$ & 20 & 31,25 \\
\hline 10 & $\begin{array}{l}\text { Durian } \\
\text { Mentega }\end{array}$ & 13 & 20,31 \\
\hline
\end{tabular}

Setelah mendapatkan Itemset 1 terpilih, langkah berikutnya adalah mencari itemset 2 dengan menggunakan rumus persamaan 2. Dari hasil perhitungan didapatkan bahwa hanya terdapat 3 kombinasi dari itemset 2 yang dapat memenuhi parameter yang telah disebutkan diatas. Adapun kombinasi tersebut dapat dilihat pada Tabel 4.

Tabel 4. Kombinasi Itemset 2 Yang Memenuhi Parameter

\begin{tabular}{|l|l|c|c|}
\hline Produk 1 & Produk 2 & Jumlah & Support \\
\hline $\begin{array}{l}\text { Kelengkeng } \\
\text { Aroma } \\
\text { durian }\end{array}$ & $\begin{array}{l}\text { Jeruk } \\
\text { Sunkist }\end{array}$ & 12 & 18,75 \\
\hline $\begin{array}{l}\text { Kelengkeng } \\
\text { Aroma } \\
\text { durian }\end{array}$ & $\begin{array}{l}\text { Durian } \\
\text { Musangking }\end{array}$ & 13 & 20,31 \\
\hline $\begin{array}{l}\text { Jeruk } \\
\text { Sunkist }\end{array}$ & $\begin{array}{l}\text { Durian } \\
\text { Musangking }\end{array}$ & 15 & 23,44 \\
\hline
\end{tabular}

Tabel 4 menunjukkan kombinasi produk yang memenuhi parameter. Dari hasil yang ditunjukkan pada tabel 4, kemudian dicari kombinasi untuk 3 


itemset dengan menggunakan
persamaan 4. Adapun hasilnya dapat
dilihat pada Tabel 5.
Tabel 5. Kombinasi Itemset 3 Yang
Memenuhi Parameter
\begin{tabular}{|l|l|l|l|c|}
\hline $\begin{array}{c}\text { Produk } \\
1\end{array}$ & $\begin{array}{c}\text { Produk } \\
2\end{array}$ & $\begin{array}{l}\text { Produk } \\
3\end{array}$ & Jumlah & Support \\
\hline $\begin{array}{l}\text { Keleng- } \\
\text { keng } \\
\text { Aroma } \\
\text { Durian }\end{array}$ & $\begin{array}{l}\text { Jeruk } \\
\text { Sunkist }\end{array}$ & $\begin{array}{l}\text { Durian } \\
\text { Musang- } \\
\text { king }\end{array}$ & 12 & 18,75 \\
\hline
\end{tabular}

Tabel 5 menunjukkan 3 kombinasi produk yang memenuhi parameter. Sehingga kombinasi tersebut yang digunakan untuk membentuk aturan asosianya.

\subsection{Pembentukan Aturan}

Pembentukan aturan asosia dilakukan setelah mendapatkan pola dengan frekuensi tinggi seperti yang sudah didapatkan pada Tabel 5. Pencarian aturan asosiasi dilakukan dengan menggunakan persamaan 4 dengan nilai minimum confidence 80 sesuai dengan parameter yang ditentukan untuk penelitian ini. Adapun hasil dari pembentukan aturan asosiasi yang telah memenuhi parameter dapat dilihat pada Tabel 6 .

Tabel 6. Aturan Asosisasi

\begin{tabular}{|l|l|c|c|}
\hline $\begin{array}{l}\text { Rule } \\
\text { X }=>\text { Y }\end{array}$ & $\begin{array}{l}\text { Support } \\
\text { X U Y }\end{array}$ & $\begin{array}{c}\text { Support } \\
\text { X }\end{array}$ & Confidence \\
\hline C, A => B & 18,75 & 20,31 & 92,31 \\
\hline B, C => A & 18,75 & 23,44 & 80 \\
\hline A, B =>C & 18,75 & 18,75 & 100 \\
\hline
\end{tabular}

Keterangan:
A: Kelengkeng Aroma Durian

B: Jeruk Sunkist

C: Durian Musangking

Tabel 6 menunjukkan aturan asosiasi yang telah didapatkan dan memiliki nilai confidence lebih dari sama dengan 80. Pada Tabel 6 terdapat Rule $X=>Y$ yang menunjukkan bahwa jika membeli ia X maka ia akan membeli Y. Seperti contoh $\mathrm{C}, \mathrm{A}=>\mathrm{B}$, yang berarti $\mathrm{C}, \mathrm{A}$ mewakili X dan B mewakili Y. Artinya jika ia membeli Durian Musangking, dan Kelengkeng Aroma Durian maka ia membeli Jeruk Sunkist.

\subsection{Evaluasi Hasil}

Setelah mendapatkan hasil aturan asosiasi seperti yang ditunjukkan pada tabel 6. Maka selanjutnya dilakukan uji lift ratio dengan menggunakan persamaan 5. Hasil yang didapatkan pada uji lift ratio ini dapat dilihat pada Gambar 2.

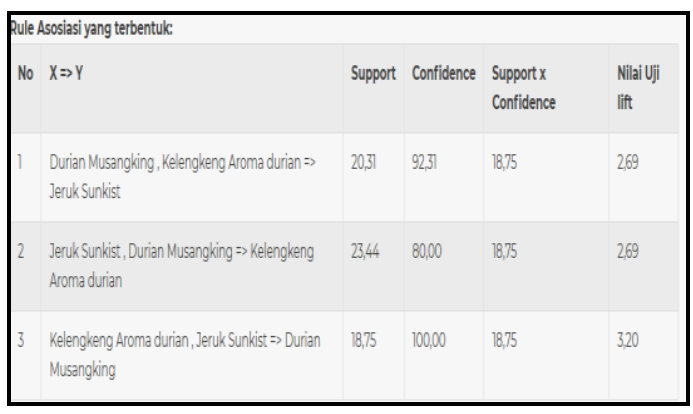

Gambar 2. Hasil Uji Lift Ratio

Gambar 2 menunjukkan hasil uji lift ratio yang telah didapatkan. Untuk lebih jelasnya dapat dilihat pada Tabel 7. 
Tabel 7. Hasil Uji Lift ratio

\begin{tabular}{|l|l|l|}
\hline $\begin{array}{c}\text { Rule } \\
\mathrm{X}=>\mathrm{Y}\end{array}$ & Confidence & $\begin{array}{l}\text { Nilai Uji } \\
\text { Lift ratio }\end{array}$ \\
\hline $\mathrm{C}, \mathrm{A}=>\mathrm{B}$ & 92,31 & 2,69 \\
\hline $\mathrm{B}, \mathrm{C}=>\mathrm{A}$ & 80 & 2,69 \\
\hline $\mathrm{A}, \mathrm{B}=>\mathrm{C}$ & 100 & 3,2 \\
\hline
\end{tabular}

Keterangan:
A: Kelengkeng Aroma Durian
B: Jeruk Sunkist
C: Durian Musangking

Tabel 7 menunjukkan hasil lift ratio yang didapatkan. Dari tabel tersebut aturan $\mathrm{A}, \mathrm{B}=>\mathrm{C}$ memiliki nilai lift ratio yang paling tinggi yaitu sebesar 3,2. Dari hasil tersebut dapat disimpulkan bahwa kombinasi paket terpilih adalah kombinasi paket antara bibit Kelengkeng Aroma Durian, Jeruk Sunkist dan Durian Musangking dengan aturan Jika membeli bibit kelengkeng aroma durian dan jeruk Sunkist maka ia membeli juga bibit durian Musangking. Hasil uji lift ratio yang dihasilkan menunjukkan nilai yang lebih besar dari 1. Hal tersebut menunjukkan bahwa perhitungan Algoritma dinyatakan valid. Berdasarkan hasil perhitungan tersebut pembentukan paket produk yang terpilih adalah Kelengkeng Aroma Durian, Jeruk Sunkist, dan Durian Musangking yang mana dapat dijadikan sebagai salah satu rekomendasi dalam pengambilan keputusan penentuan strategi pemasaran dalam bentuk paket produk.

\section{SIMPULAN}

Penerapan Algoritma apriori yang diterapkan pada data transaksi penjualan produk Taletan ijo dapat digunakan sebagai salah satu dasar pengambilan keputusan dalam strategi pemasaran yang berupa pembentukan paket produk penjualan. Dari minimal jumlah 10 dan minimal nilai confidence 80 didapatkan paket produk penjualan berupa bibit kelengkeng aroma durian, jeruk Sunkist dan bibit durian Musangking dengan nilai uji lift ratio paling tinggi sebesar 3,2 yang mana menunjukkan bahwa hasil penerapan Algoritma apriori dinyatakan valid karena hasil ujinya lebih dari 1.

\section{DAFTAR PUSTAKA}

Aziz, M. R. (2017). Implemantasi Data Mining Pada Transaksi Penjualan Bibit Buah Dengan Algoritma Apriori (Studi Kasus: UD Buah asri. Tikel Skripsi Universitas Nusantara PGRI Kediri.

Fauzy, M., Saleh, R. K. W., \& Asror, I. (2016). Penerapan metode association rule menggunakan algoritma apriori pada simulasi prediksi hujan wilayah kota bandung. J. Ilm. Teknol. Inf. Terap, 2(2), 221-227.

Firmansyah, A., \& Merlina, N. (2020). Prediksi Pola Penjualan Tiket 
Kapal Pt. Pelni Cabang Makassar Menggunakan Metode Algoritma Apriori. ITK (Jurnal Ilmu Pengetahuan Dan Teknologi Komputer), 5(2), 183-190. https://doi.org/https://doi.org/10.33 480/jitk.v5i2.1123

Fitriyani. (2015). Implementasi algoritma fp_growth menggunakan association rule pada market basket analysis. Informatika, 2(1), 296305.

https://doi.org/https://doi.org/10.31 294/ji.v2i1.85

Hermaliani, E. H., Kurniawati, L., Haryanti, T., Mutiah, N., Kurniawan, A., \& Renhoran, B. S. (2020). Data Mining Technique to Determine the Pattern of Fruits Sales \& Supplies Using Apriori Algorithm. Journal of Physics: Conference Series. https://doi.org/https://doi.org/10.10 88/1742-6596/1641/1/012070

Nst, A. H., Munthe, I. R., \& Juledi, A. P. (2021). Implementasi Data Mining Algoritma Apriori untuk Meningkatkan Penjualan. Jurnal Teknik Informatika Unika St. Thomas (JTIUST, 6(1), 188-197.

Oktaviani, A., TM Napitupul, G., Sarkawi, D., \& Yulianti, I. (2019). Penerapan Data Mining Terhadap Penjualan Pipa Pada Cv. Gaskindo Sentosa Menggunakan Metode Algoritma Apriori. Jurnal Riset Informatika, 1(4), 167-172. https://doi.org/https://doi.org/10.34 288/jri.v1i4.96

Packianather, M. S., Davies, A., Harraden, S., Soman, S., \& White, J. (2017). Data Mining Techniques
Applied to a Manufacturing SME. Procedia CIR, 123-128.

Phindika, Handrianto, Y., \& Sukmana, S. H. (2021). Application of medical equipment procurement data mining using the Apriori method. Sinkron: Jurnal Dan Penelitian Teknik Informatika, 5(2), 213-220.

https://doi.org/https://doi.org/10.33

395/sinkron.v5i2.10876

Rasyidah, H., \& Dwiasnati, S. (2021). Rekomendasi Pemilihan Peminjaman Buku Favorit Di Perpustakaan Menggunakan Algoritma Fp-Growth. Jurnal Ilmu Komputer Dan Teknologi Informasi ( Techno Explore), 6(1), 27-35.

Riszky, A. R., \& Sadikin, M. (2019). Data Mining Menggunakan Algoritma Apriori untuk Rekomendasi Produk bagi Pelanggan. Jurnal Teknologi Dan Sistem Komputer, 7(3), 103-108. https://doi.org/10.14710/jtsiskom.7. 3.2019.103-108

Rodiyansyah, S. F. (2015). Algoritma Apriori untuk Analisis Keranjang Belanja pada Data Transaksi Penjualan. Journal Infotech, 1(2), 36-39.

Romadhon, M. S., \& Kodar, A. (2020). Implementasi Metode Market Basket Analysis (Mba) Menggunakan Algoritma Apriori Dalam Transaksi Penjualan (Studi Kasus: Kafe Ruang Temu). Jurnal Saintekom, 10(2), 138-147.

Rusdiansyah, Suharyanti, N., Triningsih, \& Murniyati. (2020). Application of Pizza Sales Data Mining Using Apriori Method. 
SinkrOn: Jurnal Dan Penelitian

Teknik Informatika, 4(2), 1-5.

Sudrajat, A. W., \& Ermatita. (2021).

Penerapan Metode Asssociation

Rule Ming Dalam Pengembangan

UMKM Dengan Algoritma FP-

Growth. Prosiding Seminar

Nasional Aplikasi Sains \&

Teknologi (SNAST).

Syahrir, M., \& Fatimatuzzahra. (2020).

Integrasi Pendekatan Metode

Custom Hashing dan Data

Partitioning untuk Mempercepat

Proses Pencarian Frekuensi Item set pada Algoritma Apriori. Matrik:

Jurnal Manajemen, Teknik

Informatika Dan Rekayasa Komputer, 20(1), 149-158.

Wahyuningtias, Y., \& Rusdiansyah, R. (2019). Analisis Penerapan Asosiasi Untuk Menentukan Transaksi Penjualan Pada What's Up Café Dengan Metode Algoritma Apriori. Jurnal Riset Informatika, 1(4), 181-186.

Widjaya, S. (2017). Sistem Penunjang Keputusan untuk Menentukan Barang Terlaris dengan Algoritma Apriori pada CV Calosa Global Indonesia. -Intech: Journal of Information and Technology, 5(2), 139-146. 